References

1. Ozarto, K., Mayer, N., and Sachs, D. H. 1980. Hybridoma Cell Lines Secreting Monoclonal Antibodies to Mouse H-2 and Ia Antigens. J. Immunology. 124:533-540.

2. Long, W. I., Palombo, A., Schofield, T. L., and Eminie, E. A. 1988. Effects of Culture Media on Murine Hybridomas: Definition of Optimal Conditions for Hybridoma Viability, Cellular Proliferation, and Antibody Production. Hybridoma. 7:69-77.

3. Iscove, N. N., and Melchers, F. 1978 Complete Replacement of Serum by Albumin, Transferrin, and Soybean Lipid in Cultures of Lipopolysaccharide-Reactive B Lymphocytes. J. Exp. Med. 147:923-933.

4. Cleveland, W. L., Wood, I., and Erlanger, B. F. 1983. Routine LargeScale Production of Monoclonal Antibodies in a Protein-Free Culture Medium. J. Imm. Meth. 56:221-234.

5. Antoniades, H. N., Scher, C. D., and Stiles, C. D. 1979. Purification of $\mathrm{Hu}$ man Platelet-Derived Growth Factor. Proc. Natl. Acad. Sci. USA 76:18091813.

6. Helden, C.-H., Westermark, B., and Wasteson, A. 1979. Platelet-Derived Growth Factor: Purification and Partial Characterization. Proc. Natl. Acad. Sci. USA 76:3722-3726.

7. Maciage, T., Kelly, B., Cerundolo, J., Ilsley, S., Kelley, P. R., Gaudreau, J., and Forand, R. 1980. Hormonal Requirements of Baby Hamster Kidney Cells in Culture. Cell. Biol. Int. Rep. 4:43-50.

8. McKeehan, W.L., and Ham, R. G. 1977. Methods for Reducing the Serum Requirement for Growth in vitro of Nontransformed Diploid Fibroblasts. Dev. Biol. Stand. 37:97-108.

9. Hutchings, S.F., and Sato, G.H. 1978. Growth and Maintenance of Hela Cells in Serum-Free Medium Supplemented with Hormones. Proc. Natl. Acad. Sci. USA 79:4074-4077.

10. Wolfe, R.A., Braatz, J.A., Miller, D. A., and Heifetz, A.H. 1988. A New Serum-Free Medium for Monoclonal Antibody Production. Biotechniques. 6:62-67

11. Glassy, M.C., Peters, R. E., and Mikhalev, A. 1987. Growth of HumanHuman Hybridomas in Serum-Free Media Enhances Antibody Secretion. In Vitro Cell. \& Dev. Biol, 23:745749.

12. Higuchi, K. 1977. Cultivation of Mammalian Cell Lines in Serum-Free Chemically Defined Medium. Cell Biol. 14:131-136.

14. Barnes, D., and Sato, G. 1980. Serum Free Cell Culture: A Unifying Approach. Cell 22:649-655.

15. Stampfer, M. R., Hackett, A. J., Smith, H. S., Hancock, M. C., Leung, J. P., and Edginton, T. S. 1982. Cold Spring Harbor Conf. Cell Proliferation. 9:819-829.

16. Hammond, S. L., Ham, R. G., and Stampfer, M. R. 1984. Serum-Free Growth of Human Mammary Epithelial Cells: Rapid Clonal Growth in Defined Medium and Extended Serial Passage with Pituitary Extract. Proc. Natl. Acad. Sci. USA 81:5435-5439.

\section{CULTURE MEDIA}

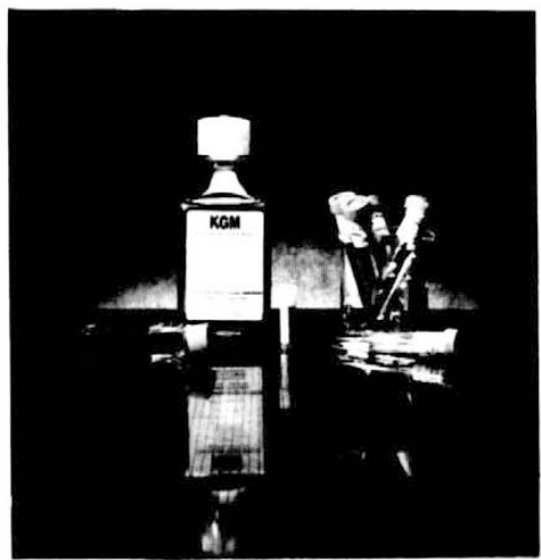

Clonetics Corp.'s (San Diego, CA) serum-free keratinocyte growth medium $\left(\mathrm{KGM}^{\mathrm{rM}}\right)$ is included in the com-

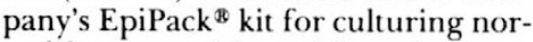
mal human epidermal keratinocytes. KGM promotes the growth of a variety of other epithelial cell types, as well, and eliminates the cytotoxicity and enzyme inactivation that can occur with serum-based media. In addition to KGM, the kit contains cultured normal human epidermal keratinocytes (NHEK), which can be used as an in vitro model for research in toxicology, cancer, dermatology, immunology, and gene expression. Established correlations between NHEK responses to irritants and those of live animals in the Draize Eye and Skin Irritancy tests offer the possibility of substituting NHEK studies for in vivo experiments.

Write in 802 on Reader Service Card

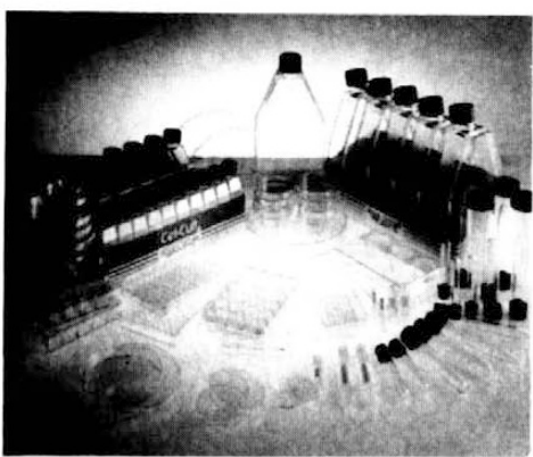

The clear, flat well bottoms of CelCult multiwell plates from Sterilin (Middlesex, U.K.) make this product useful not only for tissue culture assay systems but also for other techniques in which small samples must be kept in closed containers for microscopic examination. The plates fit standard microscope multiwell transport stages and are available sterile or non-sterile, with or without lids, and in 24- and 96-well versions.

Write in 803 on Reader Service Card

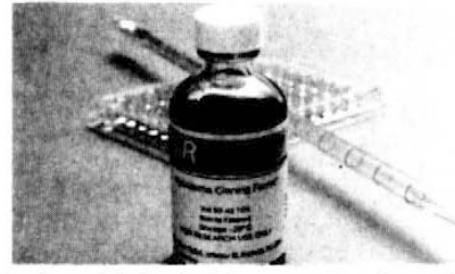

Origen $^{\text {TM }}$ hybridoma cloning factor (HCF) spurs the growth of murine hybridoma cell lines. Its manufacturer, Igen (Rockville, MD), reports that Origen HCF is more efficient and easier to use than feeder layers and conditioned media, and that it allows hybridomas to be cloned at lower cell densities. Partially purified and filtersterilized, Origen HCF is derived from continuous macrophage cell lines. It remains stable for at least six months at $-20^{\circ} \mathrm{C}$, and is supplied in $50 \mathrm{ml}$ bottles at $10 \mathrm{X}$ concentration.

Write in 813 on Reader Service Card

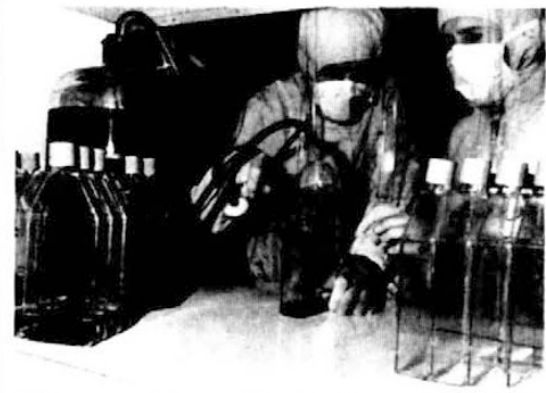

Tissue culture flasks from J. Bibby Science Products (Stone, Staffs, U.K.) rely on a canted neck design to maximize cell recovery in applications such as vaccine production. Based on a unique Corning design, Bibby flasks are strong and leak-resistant, and have a shallow profile for economical use of space when large number of flasks must be stored.

Write in 814 on Reader Service Card

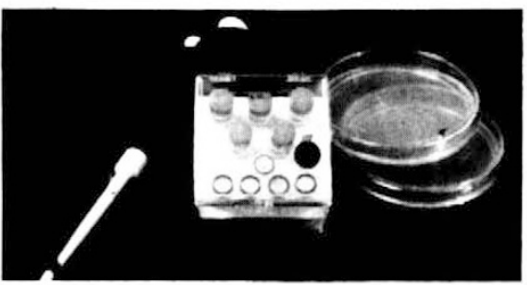

Pre-aliquoted transformation media add to the convenience of Ultra$\operatorname{comp}^{\mathrm{TM}}$, an $\boldsymbol{E}$. coli transformation kit from Invitrogen (San Diego, CA). The kit includes ultra-rich S.O.C. medium, competent $E$. coli, and prealiquoted test plasmid sufficient for 10 transformations. Invitrogen offers nine different strains of the organism, selected for insert stability and adaptability to special cloning and analysis strategies. Ultracomp kits are packaged with five aliquots of either $0.2 \mathrm{ml}$ or $1 \mathrm{ml}$.

Write in 810 on Reader Service Card 